\title{
Activity as a function of diet: II. Instrumental activity'
}

\author{
G. H. COLLIER, R. L. SQUIBB AND FLORENCE JACKSON \\ RUTGERS, THE STATE UNIVERSITY
}

\begin{abstract}
Abstraet
Rats fed isocaloric diets varying in percentage protein showed the highest rate of responding for sugar on a high protein diet and the lowest level of responding on a low protein diet. When protein was substituted as the reinforcer, the level of responding immediately dropped but eventually showed a trend in the direction of the highest rate of responding for the low protein diet and the lowest rate of responding for the high protein diet.
\end{abstract}

\section{Problem}

The voluntary intake of different items of food has been shown to vary as a function of nutritional deficits (e. g., Lepkovsky, 1948), but the question of whether reinforcing properties of dietary components vary in the same fashion has received little investigation. The present study evaluates the effect of isocaloric diets complete in all essentials and containing varying amounts of balanced protein on the reinforcing properties of sucrose and protein.

\section{Procedures and Results}

Three isozaloric diets containing 13.8. 21.3 (normal controls), and $41.3 \%$ crude protein were used; each contained 4.8 calories per gram of diet, and the known requirements of the rat for minerals, vitamins and other essentials. Food and water were constantly available.

Three groups of 12 weanling rats each were conditioned on the three experimental diets for 60 days. Figure 1 shows the typical growth curves for these diets. Following this period five representative individuals

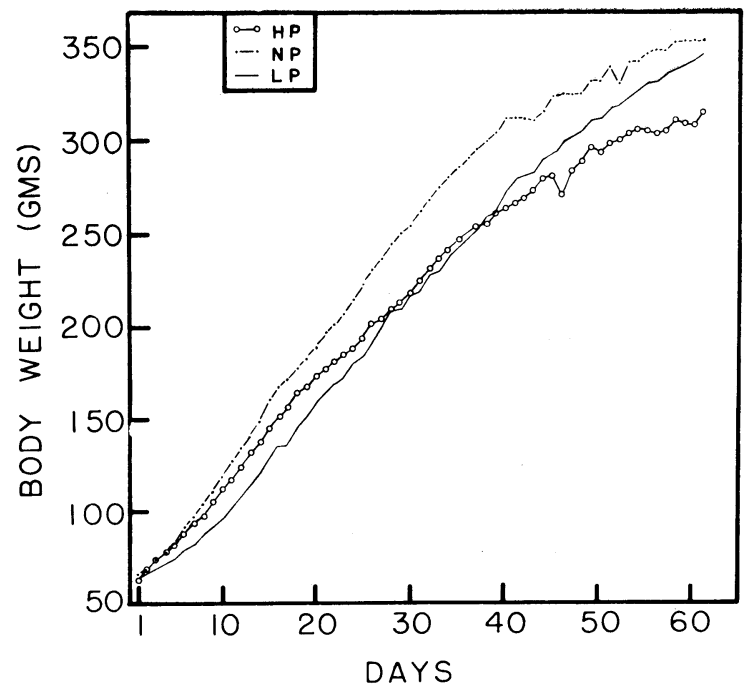

Fig. 1. Body weight as a function of diet. from each dietary regimen were trained to bar press (BP) (Collier. \& Myers, 1961) for $0.1 \mathrm{ml} \mathrm{32 \%} \mathrm{sucrose}$ reinforcement on a $1 \mathrm{~min}$. FI schedule for $20 \mathrm{~min}$. daily over an eight-day period. After these sessions the groups were then switched from sucrose to a fresh raw liver slurry reinforcement for an additional six days.

Figure 2 shows that the rats fed the high protein diet pressed significantly more for sucrose than those fed the normal level of protein. On the other hand, the rats raised on the protein deficient diet pressed significantly less than either group. When the liver slurry replaced sucrose as a reinforcer these observed differences disappeared and it was not until the final days that a trend, matching the supplemental value of the reinforcement, appeared. Food and water intake are shown in Fig. 3 and were similar to those reported in a prior experiment (Collier, Squibb, \& Jackson, 1965). Rectal temperatures taken at the end of the first 60 days of the dietary regimen, when compared to control values $\left(101,7^{\circ} \mathrm{F}\right)$, were significantly higher in the rats fed a deficiency of protein $\left(102.0^{\circ} \mathrm{F}\right)$ and lower in those fed the surfeit protein $\left(100.5^{\circ} \mathrm{F}\right)$.

\section{Diseussion}

The question can be raised as to the degree which the effectiveness of various kinds of reinforcers can be

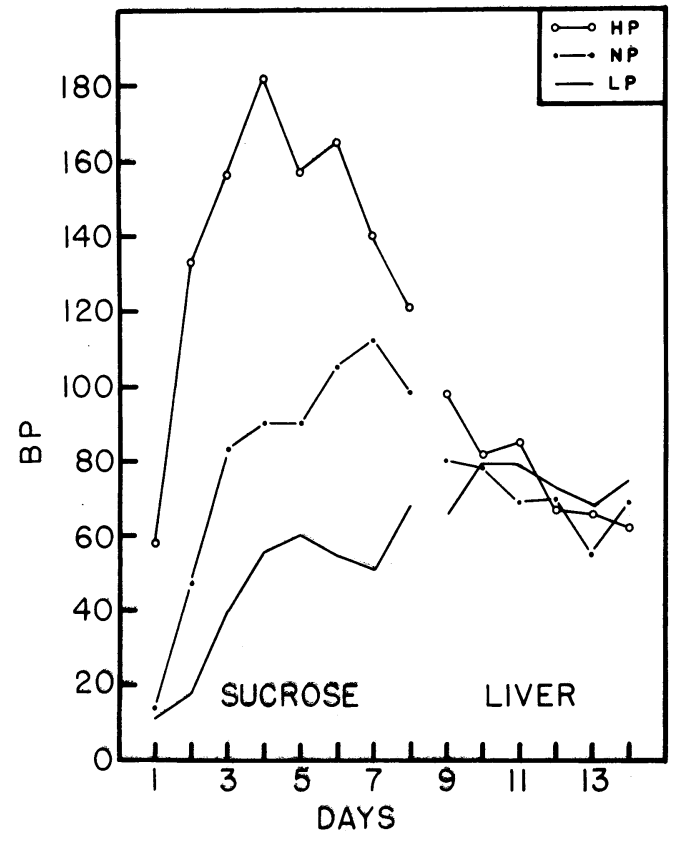

Fig. 2. Bar presses as a function of diet and of reinforcer. 


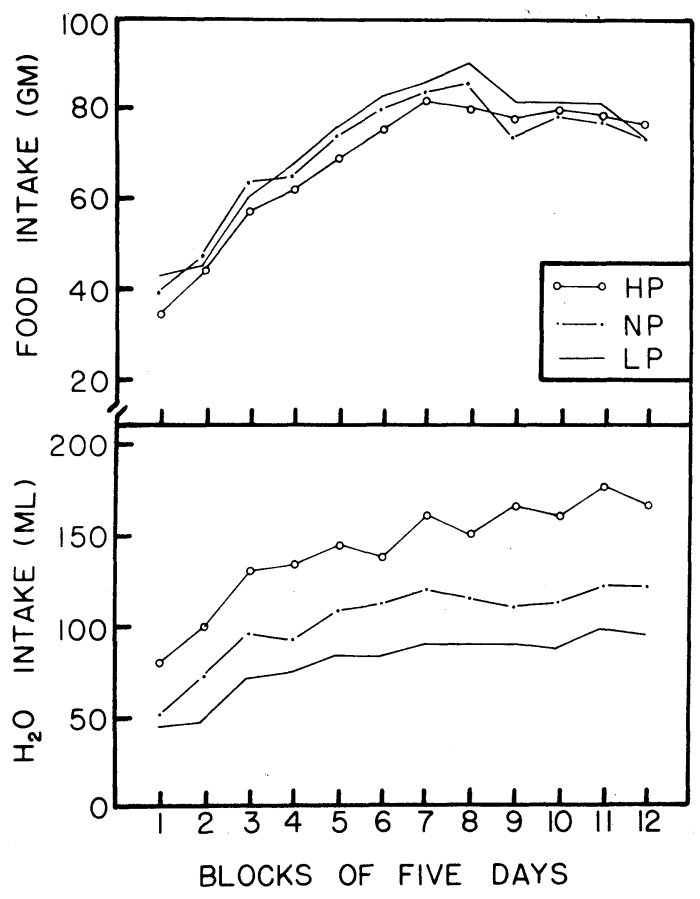

Fig. 3. Food and water intake as a function of diet. determined by the nutritional state of the animal. The present data suggest that animals consuming an adequate diet imbalanced for protein may respond instrumentally with differential strengths to substances tending to restore the balance, showing an inverse relation between activity level and instrumental performance (Collier, Squibb, \& Jackson, 1965), contrary to the predictions of conventional drive theory. In the form used, protein as a reinforcer appeared to be much less effective than sugar, however. The protein reinforcement immediately changed the level of responding but did not result in a significant inversion of rates of BP. The failure to show a significant separation, as would be predicated from the deficiencies, may have been due to the short duration of the experiment (sixdays) and/or the prior training on sucrose.

\section{References}

Collier, G., \& Myers, L. The loci of reinforcement. J. exp. Psychol., 1961, 61, 57-66.

Collier, G. H., Squibb, R. L., \& Jackson, Florence. Activity as a function of diet: I. Spontaneous activity. Psychon. Sci., 1965, 3, 173-174.

Lepkovsky, S. The physiological basis of voluntary food intakes (Appetite). Adv. Food Res. I, 1948, 46, 105-148.

\section{Note}

1. The work was supported in part by grant $\mathrm{MH} 10252$ from the United States Public Health Service, National Institute of Mental Health. 